\title{
ACCUMULATION CHARACTERISTICS ON A COLD, HIGH-ALPINE FIRN SADDLE FROM A SNOW-PIT STUDY ON COLLE GNIFETTI, MONTE ROSA, SWISS ALPS
}

\author{
$B y$ W. HAEBerLI, \\ (Versuchsanstalt für Wasserbau, Hydrologie und Glaziologie, Eidg. Technische Hochschule, \\ CH-8092 Zürich, Switzerland) \\ U. SCHOTTERER, \\ (Physikalisches Institut, Universität Bern, CH-3000 Bern, Switzerland) \\ D. WAGENBACH, \\ (Institut für Umweltphysik, Universität Heidelberg, D-69 Heidelberg, Germany) \\ H. Haeberli-Schwitter, \\ (Schützenmatt 21, CH-8046 Zürich, Switzerland) \\ and $\mathrm{S}$. BORTENSCHLAGER \\ (Institut für Botanik der Universität Innsbruck, A-6020 Innsbruck, Austria)
}

\begin{abstract}
Aвstract. In a snow pit, incorporating about 2.5 a of accumulation, on the $4450 \mathrm{~m}$ high Colle Gnifetti, Monte Rosa, various snow characteristics, isotopes $\left(\delta^{18} \mathrm{O},{ }^{3} \mathrm{H}\right)$, electrical conductivity, dust, trace elements, and pollen were investigated. The aim of this study was to develop a key for the stratigraphic interpretation of cores from cold, high-alpine firn areas. It appears that the strong influence of wind results in mixing and re sedimentation processes in the surface layers. Nevertheless, by interpreting several parameters in a combined way. it is possible to classify a large number of the layers according to their season and sometimes to their place of origin. Apart from the melt layers, which only appear in early summer to summer layers, other prominent features are the (Saharan) dust falls, characterized by dust and conductivity peaks.
\end{abstract}

RÉSumÉ. Étude des caractéristiques de l'accumulation sur un névé froid de haute-montagne au Colle Gnifetti, Mt Rose, Alpes suisses. Diverses caractéristiques de la neige, isotopes $\left(\delta^{18} \mathrm{O},{ }^{3} \mathrm{H}\right)$, conductivité électrique, poussières, trace d'éléments et pollen ont été étudiès dans une tranchée englobant environ deux ans et demi d'accumulation neigeuse afin de dèterminer une «clef» pour l'interprétation stratigraphique des carottages dans les régions de névés froids en haute-montagne sur le Colle Gnifetti (4 $450 \mathrm{~m} \mathrm{s.m}$., Mont Rose). On observe que la forte influence du vent mène à des phénomènes de mélange et de résédimentation des couches superficielles. Toutefois, sur la base de l'information tirée de la combinaison des différents paramètres observés, il est possible de dater une grande part des couches de neige et parfois d'en déterminer l'origine. En plus des horizons de glace, qui n'apparaissent que dans les couches estivales, des indices marquants sont les poussières sahariennes, caractérisées par la pointe de teneur en poussière et de conductivité.

Zusammenfassung. Untersuchung der Akkumulationscharakteristik auf einem kalten, hochalpinen Firnsattel an einem Schneeschacht auf dem Colle Gnifetti, Monte Rosa, Schweizen Alpen. An einem rund 2.5 Jahresschichten umfassenden Schneeschacht auf dem $4450 \mathrm{~m}$ hohen Colle Gnifetti, Monte Rosa, wurden diverse Schneecharakteristiken, Isotopen $\left(\delta^{18} \mathrm{O},{ }^{3} \mathrm{H}\right)$, elektrische Leitfähigkeit, Staub, Spurenelemente und Pollen untersucht. Ziel dieser Untersuchung war, einen „Schlüssel” für die stratigraphische Interpretation von Bohrkernen aus kalten, hochalpinen Firngebieten zu entwickeln. Es zeigt sich, dass der starke Windeinfluss zu Misch- und Resedimentationsvorgängen in den Oberflächenschichten führt. Aufgrund der Information aus der betrachteten Parameterkombination ist es trotzdem möglich, einen grossen Teil der Schneeschichten jahreszeitlich and z.T. herkunftsmässig einzuordnen. Markante Signale sind neben den Eislagen, die nur in Frühsommer-bis Sommerschichten auftreten, die (Sahara)-Staubfälle, die durch Staub/Leitfähigkeitspeaks charakterisiert sind. 


\section{INTRODUCTION}

Core drilling on the firn saddle of Colle Gnifetti has been in progress since 1976 (Oeschger and others, [1978]). The main aims of this project are to study the accumulation history of highaltitude firn areas and to reconstruct the development of constituents in the atmosphere since the beginning of the industrial revolution. Up to the present, dating of the cores has been based on the analyses of isotope and melt-layer stratigraphy (Schotterer and others, 1981), and the use of ${ }^{210} \mathrm{~Pb}$ data (Gäggeler and others, 1983). With an average firn temperature of about $-14{ }^{\circ} \mathrm{C}$, the annual accumulation (net balance) is on the order of 30 to $40 \mathrm{~cm} \mathrm{H}_{2} \mathrm{O}$. Amongst the most important results to date from the studies on the core samples from Colle Gnifetti are the construction of a detailed dust-fall chronology for the second half of the twentieth century (Wagenbach, unpublished) and the observation that the acidity of firn layers deposited over the last few years has clearly increased, even at high altitudes in the lower troposphere. The latter effect is probably due to the increasing acidity of precipitation (Likens and others, 1979; Schotterer and others, 1981). However, in order to interpret in detail the physical and chemical properties of the firn and ice samples from the drillings, a better knowledge of the accumulation characteristics and firn stratigraphy is needed. Several factors are of particular interest, namely, the origin and route of the precipitation, the seasonal distributions, and the mechanism of snow and aerosol deposition.

In April 1978 a snow pit on Colle Gnifetti (Fig. 1) was investigated, not only for various snow characteristics, but also for the following features: isotopes and electrical conductivity (U.S.), dust and trace elements (D.W.), and pollen (H.H. and S.B.) (the initials indicate which author was primarily concerned with a particular investigation). With this pit analysis available, the aim was to reach a better understanding of the origin, seasonal distribution, and deposition mechanism of the snow on Colle Gnifetti, and to gain experience for the stratigraphic interpretation of the core samples.

\section{OBSERVED PARAMETERS}

In addition to the snow characteristics, temperature, hardness, grain size, and ram resistance, all of which afford general information about deposition and embedding mechanisms, the stratigraphic position of the melt layers is of particular interest. On the basis of the analysis from the 1976 Colle Gnifetti core samples, it is suspected that a connection exists between air temperature, accumulation, and the formation of melt layers (Schotterer and others, 1981: see p. 264 for further discussion).

The seasonal variations of ${ }^{3} \mathrm{H}$ and $\delta^{18} \mathrm{O}$, if preserved in the core or pit, allow a dating of cold firn and ice if a count of the annual layers is made. If these layers have been disturbed or irregularly deposited, then the distinct peaks of ${ }^{3} \mathrm{H}$ produced during atomic bomb tests, such as in 1954,1958 , or $196 \dot{3}$, serve as good time checks. Since the $\delta^{18} \mathrm{O}$ in precipitation is temperature dependent, the regular deposition of this isotope would also indicate cold or warm seasons. But if the regularity is missing, and/or one has to work with single precipitation events, then high $\delta^{18} \mathrm{O}$ values do not necessarily indicate the warm season, since warm air masses can also precipitate during cold seasons.

The non-gaseous trace material in the firn layers originates essentially from the wet and dry deposition of the dust components suspended in the atmosphere. The major part of the trace 
material in the firn layers on Colle Gnifetti originates from the dispersion of eroded ground material and is, therefore, a naturally occurring mineral dust (Wagenbach, unpublished). In addition to the contribution from the continental background aerosol, it is also likely that mineral dust deposition on Colle Gnifetti could arise from a localized aerosol transported by the wind and from long-distance dust transport from arid areas (mostly Saharan dust falls: Haeberli, [1978]; Prodi and Fea, 1978; Wagenbach, unpublished). The concentrations of mineral dust in the firn on Colle Gnifetti are therefore expected to reflect distinct dust deposits (or air masses), as well as the various meteorological deposition conditions (e.g. periods free from precipitation).

Only a few pollen studies on glacier ice and firn have been made to date. Pioneer work was done by Vareschi (1942) on Aletschgletscher and on Gepatschferner. Bortenschlager (1967, 1969, 1970), working with firn samples from Kesselwandferner, confirmed Vareschi's findings and posed new questions about long-distance transport (Ephedra altissima from Africa) and pollen density. The aim of the study presented here has been primarily to develop a quantitative estimation of the pollen deposition at high altitudes and, therefore, to study the applicability of pollen analysis for accurately dating the rather limited core-sample material available (see also Krenke, 1972). The seasonal variation in pollen density was of primary interest, and wherever possible the pollen spectrum was analysed to date and to find the origin of the individual layers in the pit.

Since many of the observed parameters contain a combination of chronological and spatial information, we attempted to limit, as far as possible, the uncertainty of the interpretation by combining the various mutually independent tracers.

\section{SAMPLING AND ANALYTICAL METHODS}

Colle Gnifetti is a firn saddle, $4450 \mathrm{~m}$ a.s.l., lying between the Zumsteinspitze and the Punta Gnifetti, two summits of Monte Rosa (Switzerland/Italy, Figs 1 and 2). The saddle is extremely wind exposed and is situated in the infiltration recrystallization zone of the Alps (Shumskiy, 1955). The dry metamorphosis of snow and firn produces, at lower levels, remarkably white ice, rich in air bubbles. Such ice becomes visible in the tongue of Grenzgletscher which starts on Colle Gnifetti (Haeberli, [1976]). The $4 \mathrm{~m}$ deep pit was dug in April 1978, about $20 \mathrm{~m}$ west (towards Grenzgletscher) from the position of the 1977 core drilling.

The usual standard methods were used for the examination of the snow characteristics. The sequence of individual layers was established according to the differences in hardness on the wall of the pit. The samples for pollen analysis (about $1000 \mathrm{ml}$ in volume) were taken from the wall of the pit with a hand drill and were processed and analysed immediately after the field work, using standard methods. Samples for the examination of the trace elements were taken under extremely clean conditions, parallel to those used for the other analyses $\left({ }^{18} \mathrm{O},{ }^{3} \mathrm{H}\right.$, conductivity, and pollen). The resulting depth uncertainty for both sets of samples was estimated to be $\pm 5 \mathrm{~cm}$. The firn samples were stored in precleaned polyethylene containers and shipped in a frozen state to the laboratory. Three centimetres of the surface of each firn block was trimmed back using acid-cleaned quartz and polycarbonate tools in order to reduce possible contamination. Traceelement analysis was performed by an energy-dispersive X-ray fluorescence system, using "thinfilm" fluorescence techniques.

An estimation of the mineral dust content of the firn sample was determined by measuring the titanium content of the filtered residue (particle size, $d>0.1 \mu$ ), as well as the calcium and 


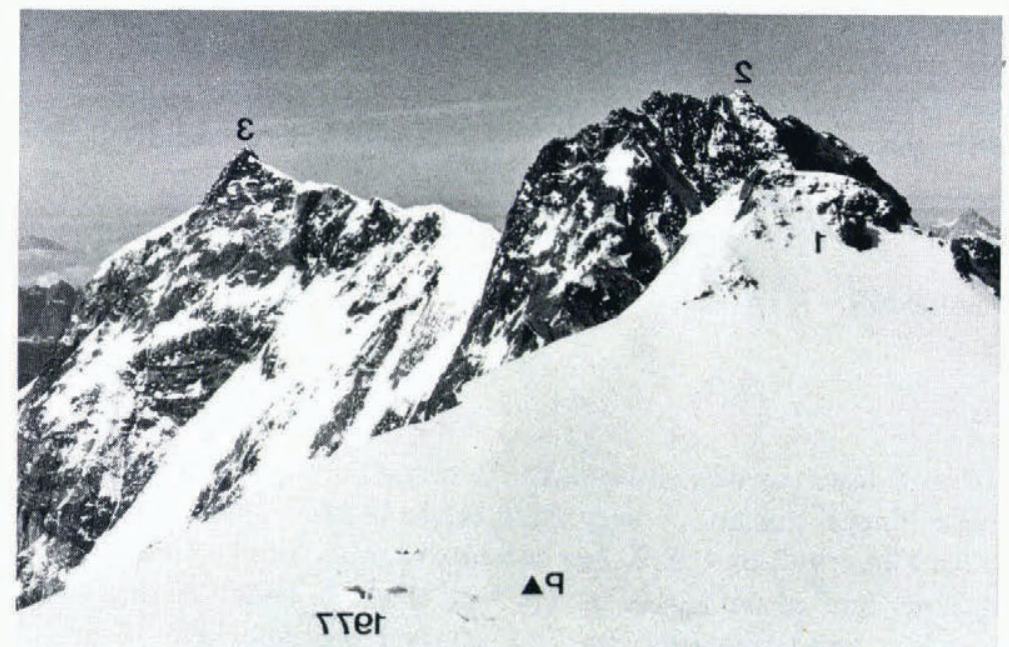

Fig. 1. Colle Gnifetti from the Capanna Regina Margherita (Punta Gnifetti). $P=$ snow pit described in this contribution, $1977=$ drill site $1977,1=$ Zumsteinspitze $4563 \mathrm{~m}$ a.s.l., $2=$ Dufourspitze $4634 \mathrm{~m}$ a.s.l., $3=$ Nordend 4609 m a.s.l. Photograph: W. Haeberli, August 1977.

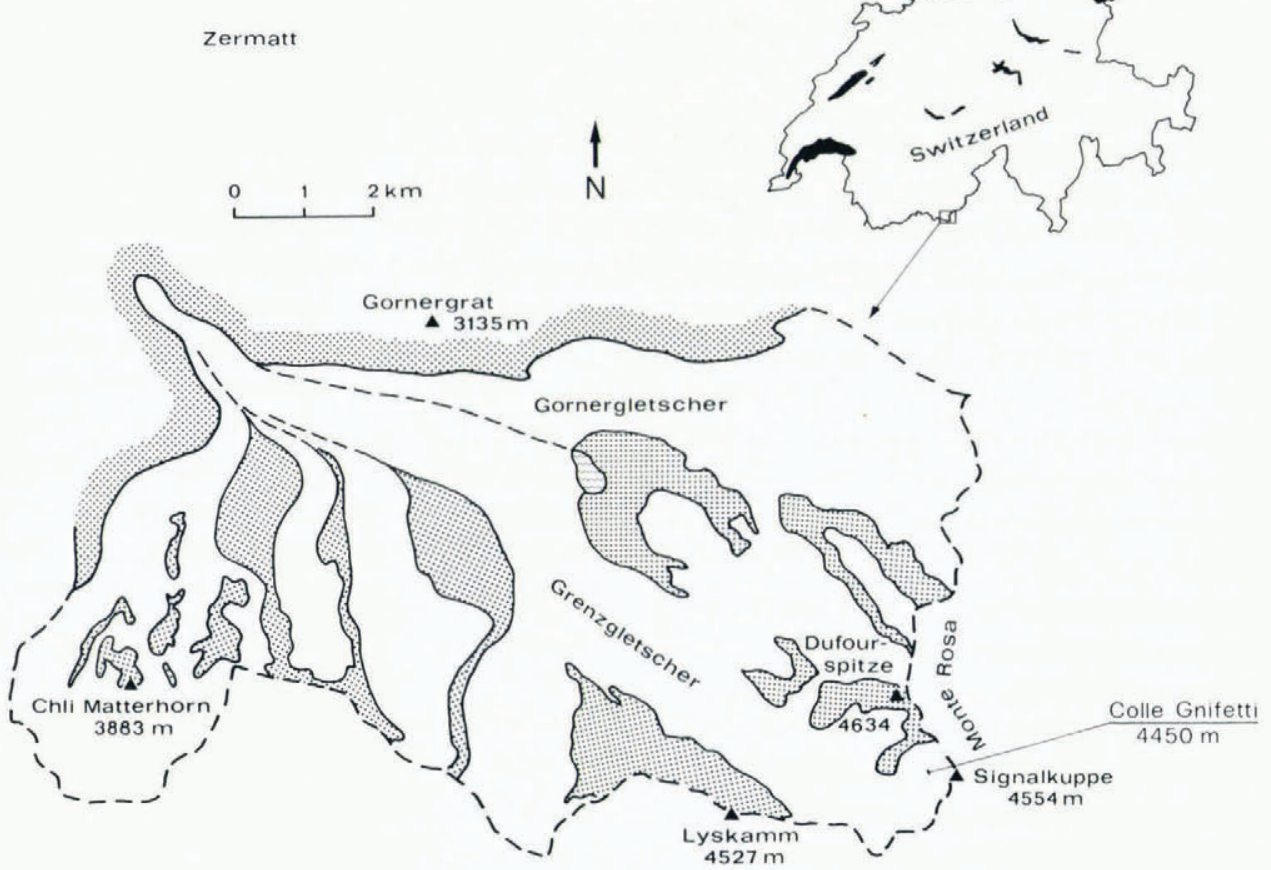

Fig. 2. Situation and location map Grenzgletscher/Colle Gnifetti. 
potassium contents. Since naturally occurring titanium compounds are barely soluble, the average concentration of titanium in the Earth's crust allows an estimation of the mineral dust content of the whole sample (detailed description of the procedure in Wagenbach, unpublished). ${ }^{3} \mathrm{H}$ was measured by gas proportional counting and $\delta^{18} \mathrm{O}$ with a mass spectrometer.

\section{RESULTS AND DISCUSSION}

\section{Snow characteristics}

Except for the soft layer of new snow (layer 0, penetrable by hand), the layers are always medium-hard, hard (finger-pencil), or very hard (knife blade). Thickness and number of the medium-hard to hard layers $(2$ to $4,6,8,12)$ decrease rapidly with increasing depth, practically the whole of the upper half of the pit being very hard (Fig. 3). Especially hard layers appear in the ram profile as thin wind crusts (layers 1, 7, 10, and probably also 18 and 20). The ram resistance in the lower half of the pit is about $50 \mathrm{~kg}$. These values are comparable to the ram resistances measured in the winter snow cover of the Alps above the timber line ("Winterberichte Weissfluhjoch/Davos"), or in Greenland at about $1500 \mathrm{~m}$ a.s.l. (Benson, 1959). This is a clear indication of the strong influence which the wind has on the deposition of snow. It must be assumed, therefore, that erosion, transport, swirling, and re-deposition of snow all play an important role on Colle Gnifetti.

The average grain size in the individual layers does not exceed one millimetre in diameter. and the snow has to be classified as fine-grained or very fine-grained. The layers in the upper half of the profile containing the largest grain $(1 \mathrm{~mm}$, layers $3,6,12)$, are relatively soft layers in the hardness profile. This disappearance of these layers in the lower half of the profile therefore indicates that the relatively soft layers are quickly compressed by a destructive metamorphosis of the larger grains. The small grain diameter and the slightly angular shape of the grains show that the snow in the respective layers has not undergone melting and has probably never experienced temperatures greater than $-5^{\circ} \mathrm{C}$ (Benson, 1959). The snow temperature varies between $-14.5^{\circ} \mathrm{C}$ and $-18.5^{\circ} \mathrm{C}$. As is to be expected in spring (April), the snow temperature is not far below the mean annual firn temperature and the temperature gradient is small, except for small variations of short wavelength (temperature variations of short duration on the surface).

A very conspicuous coloured band of red dust in layer 13 can be dated from the large Saharan dust fall in May 1977 (Oeschger and others, [1978], fig. 2). A less prominent dust band is found in layer 3 . The lower edge of the red colour in layer 13 is sharp, but the upper boundary is diffuse (Fig. 3). Clear ice layers mark the summers of 1977 (layers 11, 13) and 1975 (pit bottom, not included in the samples), and between these there must have been a summer with no ice formation (see below, ${ }^{3} \mathrm{H}$ measurements). The ice bands are thin layers of frozen firn. These can be traced, without major disruptions, on the side walls of the pit. In addition to these signs of surface melting, a vertical ice channel was observed in the Saharan dust layer 13. This is the only indication to date of vertical melt-water flow on Colle Gnifetti.

The melt layers indicate that the pit profile spans about 2.5 a: the snow layers contain very fine grains and are wind compressed. Snow temperatures well below $0{ }^{\circ} \mathrm{C}$ have limited melting to the surface, vertical melt-water transport (within an annual layer) is rare (only in Saharan dust layers), and in some years the formation of melt water and ice layers is totally absent. 


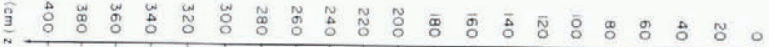

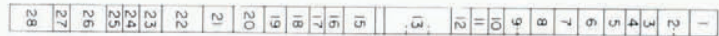

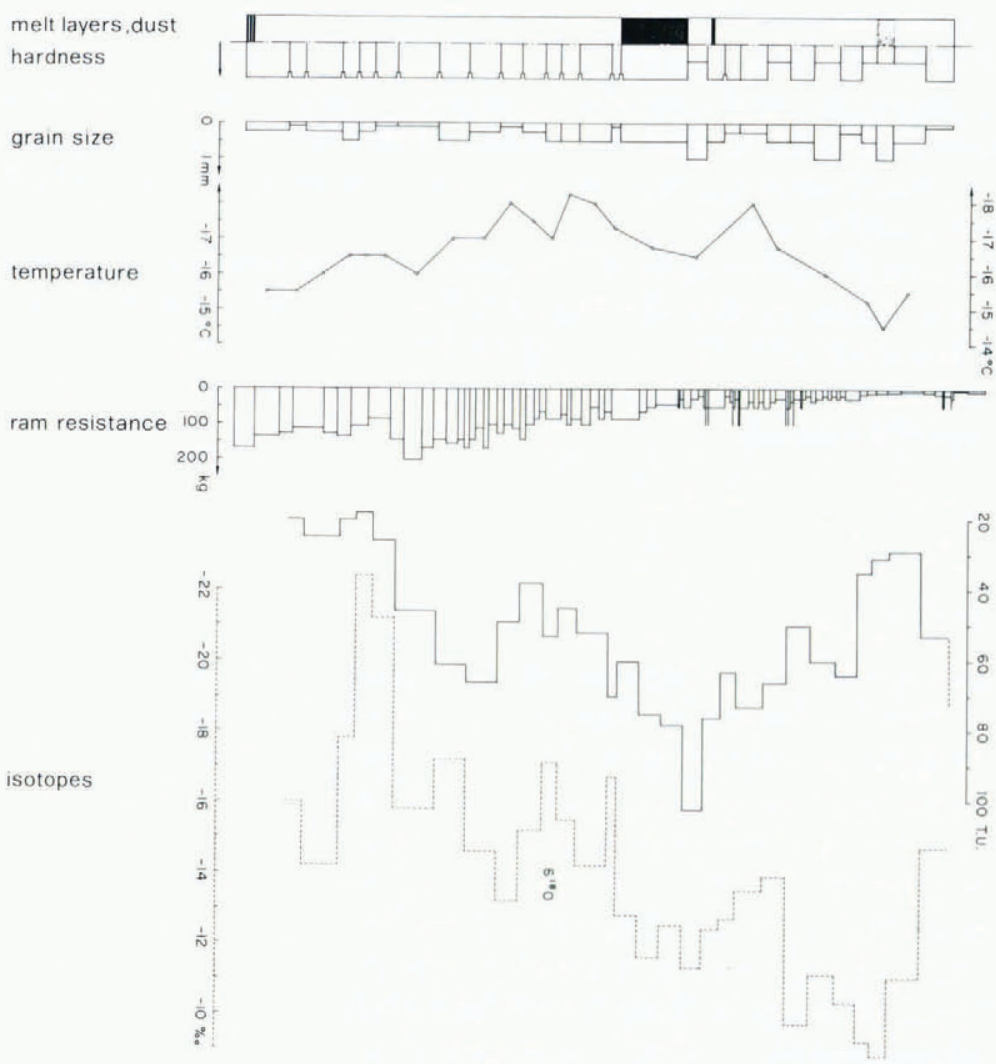

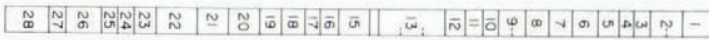

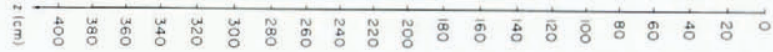

Fig. 3. Snow characteristics and isotopes in the snowpit. $1-28=$ layer numbers.

\section{Isotopes}

The tritium concentration (Fig. 3) shows two maxima and three minima. These mark two summer and three winter periods, according to the seasonal variation in tritium concentration found in precipitation. It has to be assumed that any short-term re-suspension and resedimentation of individual snow layers did not significantly change the deposition pattern of tritium over longer periods of time (several months or even years). The profile goes back accordingly to autumn/winter $1975 / 76$ and, using an average density of $0.4 \mathrm{Mg} \mathrm{m}^{-3}$, thus gives 
an annual accumulation of about $0.55 \mathrm{~m}$ w.e. per year. The weighted mean value in the pit of 51.5 TU matches the weighted mean of precipitation in Locarno between September 1975 and April 1978 (52 TU). On the north side of the Alps, this value is considerably higher for the same time period (91 TU). The firn accumulation on Colle Gnifetti during this time could basically be attributed to precipitation from the south, since the low values indicate maritime influence (ocean surface about $10 \mathrm{TU}$ ). Moreover, around 1976, fairly direct transport occurred because the air masses did not, apparently, hold very much continental water vapour (continental air masses have a high tritium content). It is, however, to be noted that when comparing tritium values from the pit and from precipitation, the latter are available as monthly averages, whereas in the pit some precipitation could be missing.

The sort of seasonal variation in the $\delta^{18} \mathrm{O}$ known from precipitation measurements cannot be expected to occur in Alpine glaciers (Oeschger and others, [1978]; Schotterer and others, 1981). It is only possible to associate $\delta^{18} \mathrm{O}$ maxima and minima with individual summer or winter layers if other, unrelated parameters confirm this (the 1977/78 winter section of the pit shows, for example, very high $\delta^{18} \mathrm{O}$ values).

\section{Conductivity and dust}

Electrical conductivity, as an indication of the total ion content, was measured immediately after melting the samples. Increased values in the layers 3, 7, 12/13, and 22 contrast with the mean "noise" of about $3.5 \mu \mathrm{S} / \mathrm{cm}$ (Fig. 4). The mineral dust profile, with the titanium content as the key parameter (Fig. 4), contains at least two further incidents of dust falls, in addition to the extreme dust fall in May 1977 (samples 3, 7/8, 12). Indications of this are given by the red colour of the filtered residue which also contains five to ten times more $\mathrm{Ca}$ than the local rock and cryoconite material. It was not possible to record incidents of dust falls in the lower half of the profile (from sample 13). This is consistent with the observations by Prodi and Fea (1978) on the neighbouring Plateau-Rosa and with the lack of marked conductivity peaks in the corresponding layers in the Colle Gnifetti pit.

The average mineral dust content in the layers probably unaffected by a specific dust fall is about $0.68 \mathrm{mg} / \mathrm{l}$ (corresponding to $3 \mu \mathrm{g} / \mathrm{l}$ titanium). An average value of $0.6 \mathrm{mg} / \mathrm{l}$ was recorded in a core sample on Colle Gnifetti taken from the top $24 \mathrm{~m}$. This value is within the range expected for an area with extremely clean air. The same is also true for the specific terrigenous trace elements Fe, K, Ca, Mn, and Sc (Wagenbach, unpublished). The mineral dust content of the samples of fresh snow in the years $1977-80$ was $23-140 \mu \mathrm{g} / \mathrm{l}$, clearly lower than that of the pit samples. It has to be assumed, therefore, that a significant part of the suspended material is subsequently deposited in dry form. It could be possible that the surface snow is repeatedly recast (high wind velocities), thus incorporating additional dry deposits into the layer.

Snow layers with extremely low dust contents (samples 10 and 11, also 22-21) are not necessarily associated with correspondingly low atmospheric dust concentrations. Rather, they could originate from fresh snow which was only deposited once, and which has been protected by hard surface layers, such as melt layers, crusts, etc. This snow was therefore not exposed either to aerosol dry deposition or to mixing processes.

An annual pattern with distinct dust minima in winter, due to the existence of snow cover in lower regions, such as was measured in air samples on Jungfraujoch by Dams and de Jonge 


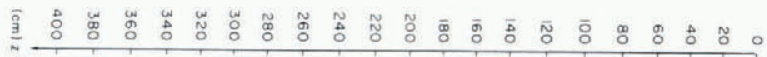

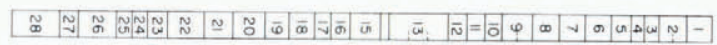
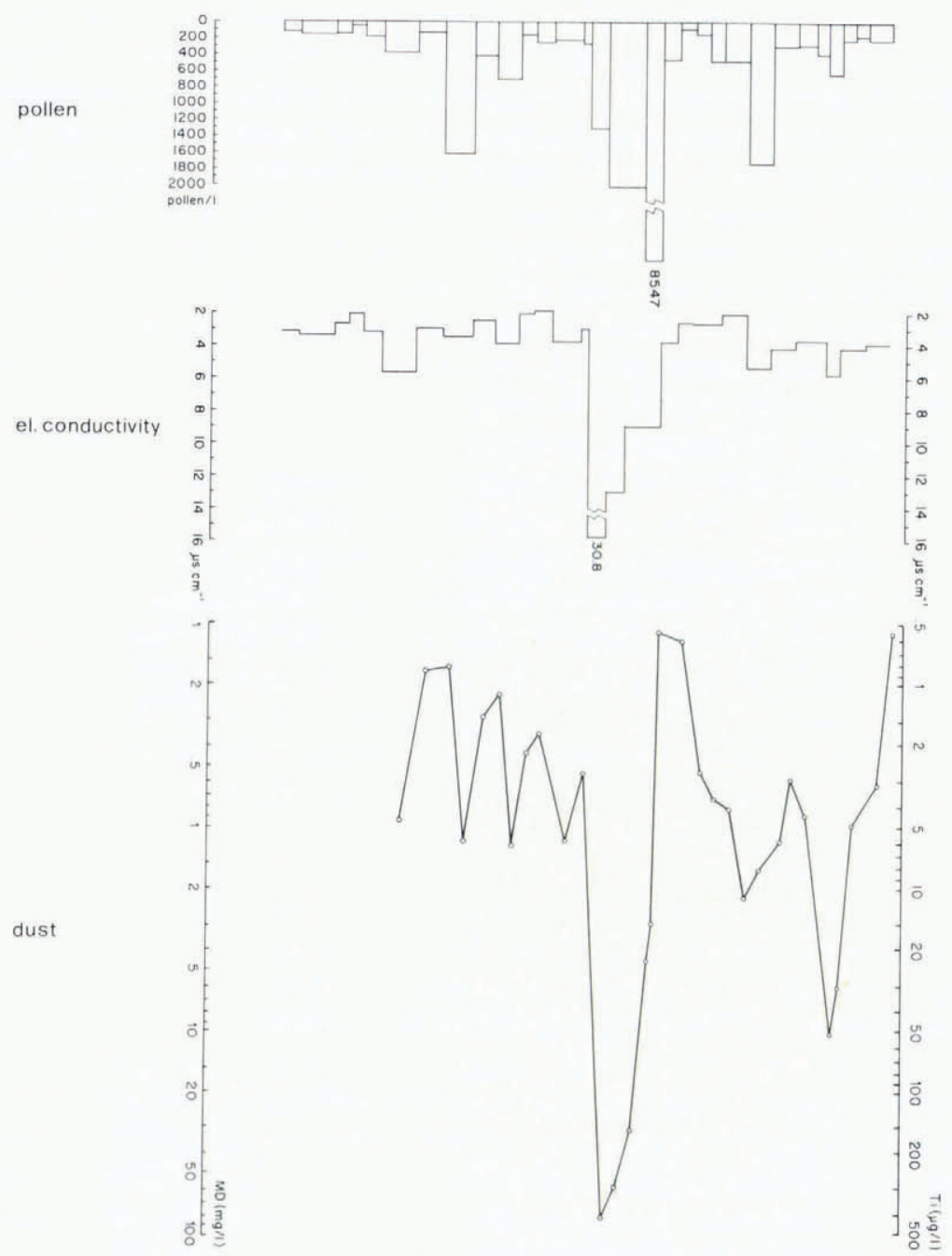

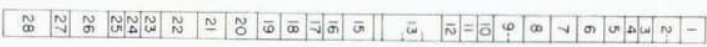

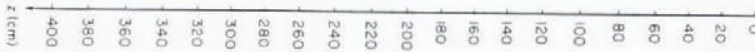

Fig. 4. Pollen, electrical conductivity, and dust in the snow pit. $1-28=$ layer numbers as in Fig. 3.

(1976), does not appear in the pit profiles (nor does it in the core sample profile of Colle Gnifetti). This is probably due to extensive mixing and losses of surface snow, as is the case with the relatively weak seasonal fluctuations in the pollen and $\delta^{18} \mathrm{O}$ values. 


\section{Pollen}

The extreme maximum in layer 12 (about 8500 pollen/l) is striking in the pollen density profile (Fig. 4). Layers 7, 13(a,b,c), and 20 also show relatively high pollen concentrations (1 300-2 100 pollen/l). The other samples, with the possible exception of samples 3 and 18 (600-700 pollen/l), fall within the values for the atmospheric background concentration. In total, the precipitation of pollen during 1976/77 comes to about $6000-7000$ pollen year ${ }^{-1} \mathrm{dm}^{-2}$, if the extraordinary Alnus precipitation in layer 12 is not taken into account. Compared to the pollen precipitation in the firn profile from Kesselwandferner $(3000 \mathrm{~m}$ a.s.l., 28000 pollen year ${ }^{-1} \mathrm{dm}^{-3}$ ), this corresponds to a reduction of about four to five times. Pollen density values over 1000 pollen/l are only observable in layers formed between early summer and autumn; extremely low values occur mainly-but not exclusively - in winter layers. Because of this, pollen analysis could also be used here, to distinguish between summer and winter layers in the core samples, though a requisite sample size (about 0.51 water) corresponds to a layer of about six months in the core samples from Colle Gnifetti.

A further problem is the apparent mixing of deposited, re-swirled, and re-deposited snow. The sequence of layers $13 \mathrm{c} / 13 \mathrm{~b} / 13 \mathrm{a} / 12$ is particularly interesting in this respect (Table $\mathrm{I}$ ).

The highest dust concentration was measured in the lowest layer (13c), directly above the sharp colour boundary attributed to the Saharan dust fall from 19 May 1977 (Fig. 4). In the layers immediately above, the dust concentration decreases regularly, but the pollen density, on the other hand, increases regularly. Superimposed on this is an enormous precipitation of Alnus (about 5300 pollen/l) in layer 12 and just beginning in layer $13 \mathrm{a} / \mathrm{b}$, and this indicates precipitaton in May/June. The layers 13 and 12 appear to be partly mixed together, yet the mixing has probably occurred within a very short time, since another early summer precipitation follows in layer 11, containing strongly dominant Pinus and Alnus pollen.

Despite the uncertainty in deducing seasonal sequences from pollen densities, individual events can be interpreted with fair certainty. In layer 3, for example, there is a winter precipitation from the south (Artemisia and Cupressaceae), in layer 7 a late summer precipitation from the south (Ephedra, Castanea, Urtica spp., etc.), in layer 10, protected under a wind crust, a low-dust, early-summer, fresh snow-fall (Quercus), and layer 20 may be a May/June precipitation which did not originate in the south (Fraximus, Quercus, Gramineae spp.).

In order to test a further possibility for the pollen analysis of core samples, some filtered residues from the dust analysis were also analysed for pollen content. Since the small quantities of water being analysed could only be expected to contain low pollen concentrations, the filter and its contents were dissolved on a microscope slide using a chloroform-bromoform mixture. This allowed a quantitative evaluation of the samples to be made.

The filter samples treated in this way showed a pollen content which was much too low compared to previous analyses of pollen in the layers, and, in fact, some samples were

TAble I. Pollen densites

$\begin{array}{lccc}\text { Sample number } & \begin{array}{c}\text { Pollen density } \\ 1^{-1}\end{array} & \begin{array}{c}\text { Ephedra } \\ \text { per cent }\end{array} & \begin{array}{c}\text { Alnus } \\ \text { per cent }\end{array} \\ 12 & 8547 & 2 & 62 \\ 13 \mathrm{a} / \mathrm{b} & 2014 & 0 & 15 \\ 13 \mathrm{c} & 1305 & 5 & 0\end{array}$


apparently free of pollen. One possible explanation for this could be that the pollen grains may have been shaken out following their storage in the filter or during their transport. In order to eliminate this possible source of error, the preparation for the pollen analysis would have to be made immediately after filtration or the pollen would have to be fixed on the filter e.g. using glycerine. It ought to be possible to process the filtered residue with a view to measuring the pollen content of ice, using the filtered samples from the dust analysis, but more experimentation is still needed.

\section{Conclusions}

The dust and pollen analyses illustrate the difficulties in analysing the firn from the extremely wind-exposed and high-altitude Colle Gnifetti. The mineral dust profile for the firn on Colle Gnifetti is dominated by the large peaks from dust-fall events. The variations beyond the dust layers cannot be directly related to corresponding variations in the atmospheric dust concentrations without knowing the respective meteorological conditions up to the final snow deposition (wind, ice-crust development, etc.). Occurrences of mixing in the surface layers combined with aerosol dry deposition could mean that low trace-material signals, especially those of minimal concentration, would rarely be seen in the profiles. Neither the dust nor the pollen profile shows a clear annual pattern; relative minima for both parameters occur in the infrequently preserved fresh snow layers.

Other signs are, on the other hand, clear. Even if there is no quantitative connection between, for example, dust and conductivity, both profiles are, nevertheless, very similar. Clear, high conductivity values were found in layers with very high dust concentrations; in other words, high peaks in the conductivity signal in most cases probably indicate long-distance dust transportation. Layers with very low dust concentrations are mostly coupled with low conductivity values. Since it is not yet certain whether or not all dust falls in the Alps originate from North Africa, it is important to localize the area of origin of the dust transport. This may be possible by analysing the pollen in layers with high mineral-dust concentration.

By considering all the parameters together, namely melt layers, isotopes, dust, and pollen, 19 out of the 22 layers can be given a seasonal classification, allowing a detailed chronology to be produced. Of the 16 such layers corresponding to the time period between spring 1976 and spring 1978 (layers 21 to 0), seven can be associated with winter (layers 2 to 4,15 to 18), three with spring (layers $0,12,13$ ), five with early summer to summer (layers 9 to 11, 20, 21) and one with autumn (layer 7). Initially, erosional gaps are to be sought in autumn. The accumulation between winter $1975 / 76$ and winter $1976 / 77$ is about $40 \mathrm{~cm} \mathrm{H}_{2} \mathrm{O}$, approximately within the range of the values observed in the core samples. The accumulation observed in the following year up to winter $1977 / 78$ is considerably higher, $65 \mathrm{~cm} \mathrm{H}_{2} \mathrm{O}$, a value which is clearly larger than the $0.35 \mathrm{~m}$ w.e. obtained from the core drilling of 1976 . This second year also shows high values for dust deposition and ${ }^{18} \mathrm{O}$ concentration, as well as pronounced melt-layer formation. All the snow layers which definitely originate from the south are to be found in the upper half of the profile (layers 1 to $4,7,12,13,19$ ).

Melt layers are thought to protect against wind erosion, an important feature on Colle Gnifetti and, thereby, the net balance (annual accumulation rate) is increased. Schotterer and others (1981) used an empirical relationship between air temperature, melt-layer thickness, and accumulation rate to extrapolate tritium datings for the core of 1976. Saharan dust falls bring 
warm precipitation from the south and lower the albedo of the snow surface. Melt-layer formation is thereby enhanced and their protective influence reinforced. A good example of this effect can be seen in the coloured layer 13, which not only contains the extreme dust fall from 19 May 1977, but also has thick melt layers. This layer alone accounts for over $50 \%$ of the excess in accumulation in 1977.

It is also relevant to note that $\mathrm{pH}$ measurements performed on core samples show higher values than expected for the snow layers containing Saharan dust (Wagenbach, unpublished). This result is a consequence of the buffer effect of calcium and magnesium carbonates present in the dust.

The correlations which now emerge from the results of accumulation, $\mathrm{pH}$, dust, and ice-lens studies done since about 1940 (Schotterer and others, 1981, figs 5 and 6, p. 54; Wagenbach, unpublished, fig. 6, p. 37a), are therefore no longer so surprising.

The following parameters turn out to be the clearest indicators:

melt layers: indicate melting processes at or very near the surface and occur in early and high summer snow. They are the most reliable indication of summer, but can be missing occasionally (precipitation from the north, no Saharan dust falls).

electrical conductivity: high values in connection with high dust contents indicate long distance transport, probably from the south.

${ }^{3} \mathrm{H}$ : pronounced maxima indicate spring or early summer layers, pronounced minima could indicate winter layers or air masses of marine origin. However, annual variations do not always exist.

${ }^{18} \mathrm{O}$ : high values indicate either summer layers or precipitation from warm air masses, low values correspond to winter layers or precipitation from continental (cold) air masses. This parameter can only be used in connection with other time indicators or with those which indicate the origin of the precipitation, but then it provides important information.

dust: very high concentrations occur with long-distance transport from the south. The concentrations remain very low when fresh snow layers are protected from erosion (melt layers, wind crusts).

pollen: can contain important information about the origin and date of a sample. The applicability of the pollen analysis in the interpretation of core samples depends especially upon whether dust filters can be used for the investigation or not, and, therefore, whether or not the problem of the sample size can be solved.

Using this key to interpretation, it may be possible to classify at least part of the core samples in terms of time and place of origin. A relatively large number of samples which do not show prominent characteristics probably contain re-deposited, swirled material and render average "noise" conditions rather than specific regional information.

\section{ACKNOWLEDGEMENTS}

Thanks are due to $\mathrm{Dr} \mathrm{H}$. Röthlisberger, Professor $\mathrm{Dr} \mathrm{H}$. Oeschger and Professor Dr K.-O. Münnich for encouragement and criticism. Pamela Alean assisted in the preparation of this publication. Financial support was given by ETH Zürich, Schweizerischer Nationalfonds, and Deutsche Forschungsgemeinschaft. 


\section{REFERENCES}

Benson, C. S. 1959. Physical investigations on the snow and firn of northwest Greenland, 1952, 1953, 1954. U.S. Snow, Ice and Permafrost Research Establishment. Research Report 26.

Bortenschlager, S. 1967. Pollenanalytische Ergebnisse einer Firnprofiluntersuchung am Kesselwandferner (3 240 m. Ötztal, Tirol). Grana Palynologica, Vol. 7, No. 1, p. 259-74.

Bortenschlager, S. 1969. Pollenanalyse des Gletschereises-grundlegende Fragen zur Pollenanalyse überhaupt. Berichte der Deutschen Botanischen Gesellschaft, Bd. 81, Ht. 11, p. 491-97.

Bortenschlager, S. 1970. Neue pollenanalytische Untersuchungen von Gletschereis und gletschernahen Mooren in den Ostalpen. Zeitschrift für Gletscherkunde und Glazialgeologie, Bd. 6, Ht. 1-2, p. 107-18.

Dams, R., and Jonge, J. de. 1976. Chemical composition of Swiss aerosols from the Jungfraujoch. Atmospheric Environment, Vol. 10, No. 12, p. 1079-84.

Gäggeler, H., and others. 1983. ${ }^{210} \mathrm{~Pb}$-dating of cold alpine firn/ice cores from Colle Gnifetti, Switzerland. by H. Gäggeler, H. R. von Gunten, E. Rössler, H. Oeschger, and U. Schotterer. Journal of Glaciology, Vol. 29, No. 101, p. 165-77.

Haeberli, W. [1976.] Eistemperaturen in den Alpen. Zeitschrift für Gletscherkunde und Glazialgeologie. Bd. 11, Ht. 2, 1975, p. 203-20.

Haeberli, W. [1978.| Sahara dust on the Alps-a short review. Zeitschrift für Gletscherkunde und Glazialgeologie. Bd. 13, Ht. 1-2, 1977, p. 206-08. [Appendix to Oeschger and others ([1978|).|

Krenke, A. N. 1972. Water percolation through the firn body of "temperate" glaciers and formation of glacial runoff according to IHD Marukh representative basin. [Union Géodesique et Géophysique Internationale. Association Internationale d'Hydrologie Scientifique.| Symposium on the results of research on representatice and experimental basins. [Wellington, N.Z., 1970.] Vol. 2, p. 88-101. (Publication No. 97 AIHS.)

Likens, G. E., and others. 1979. Acid rain, by G. E. Likens, F. W. Richard, J. N. Galloway, and T. J. Butler. Scientific American, Vol. 241, No. 4, p. 39-47.

Oeschger, H., and others. [1978.] First results from alpine core drilling projects, by H. Oeschger, U. Schotterer. B. Stauffer, W. Haeberli, and H. Röthlisberger. Zeitschrift für Gletscherkunde und Glazialgeologie. Bd. 13. Ht. 1-2, 1977, p. 193-208.

Prodi, F., and Fea, B. 1978. Transport and deposition of Saharan dust over Alps. Veröffentlichungen der Schweizerischen Meteorologischen Zentralanstalt, 40, p. 179-82.

Schotterer, U., and others. 1981. Datierung von kaltem Firn und Eis in einem Bohrkern vom Colle Gnifetti, Monte Rosa, [von] U. Schotterer, W. Haeberli, W. Good, H. Oeschger, und H. Röthlisberger. Jahrbuch der Schweizerischen Naturforschenden Gesellschaft, wissenschaftlicher Teil, 1978, p. 48-57.

Shumskiy, P. A. 1955. Osnovy strukturnogo ledovedeniya: petrogafiya presnogo l'da kak metod glıatsiologicheskogo issledovaniya. Moscow, Izdatel'stvo Akademii Nauk SSSR. [English translation: Principles of structural glaciology: the petrography of fresh-water ice as a method of glaciological investigation. Translated from the Russian by David Kraus. New York, Dover Publications, 1964.|

Vareschi, V. 1942. Die pollenanalytische Untersuchung der Gletscherbewegung. Veröffentlichungen des Geobotanischen Institutes Rübel in Zürich, 19. Ht.

Wagenbach, D. Unpublished. Pilotstudie zur Aerosoldeposition auf einer hochalpinen "kalten" Firndecke. |Ph.D. thesis, Universität Heidelberg, 1981.|

"Winterberichte Weissfluhjoch/Davos". Schnee und Lawinen in den Schweizer Alpen. Winterberichte des Eidg. Institutes für Schnee- und Lawinenforschung (Weissfluhjoch/Davos). |Annual reports.| 